\title{
Environmental awareness, consumption, and labor supply: Empirical evidence from household survey data
}

\begin{abstract}
What is the effect of environmental awareness on the households' consumption of polluting goods and labor supply decisions? We answer this question using household survey data from the United States and measuring environmental awareness with the decision to make environmental donations. We find that environmental awareness has a negative and economically significant effect on labor supply. The respective impact on the consumption of polluting goods is also negative, but less robust in terms of statistical significance. Our results highlight the importance of understanding the foundations of household behavior related to environmental quality. Indeed, environmentally aware households are willing to tradeoff work hours with improved environmental quality and less so to change their consumption habits.
\end{abstract}




\section{Introduction}

How does environmental awareness affect a household's decision making? The increasing environmental concerns of individuals, especially in high-income economies, place the answer to this question in the center of the agenda of researchers and policy makers alike. Our premise is that higher environmental awareness should change the labor/leisure decisions, as well as the consumption decision of individuals especially against polluting goods. This is the first study aiming to empirically analyze these potential effects of increasing environmental awareness using representative household-level survey data.

Our study is primarily motivated by the policy-relevant debate on the rising environmental awareness of individuals and households. The GfK (2011) report suggests that compared with 1990s, twice as many U.S. citizens are buying products made from packaged or recycled materials (29\%), and cutting down on their automobile usage by taking mass transit (18\%). Also, according to the 2001 wave of the Panel Study of Income Dynamics (PSID), $4.5 \%$ of the respondents make environmental donations of some form, while this number increases to $6.4 \%$ in the 2011 wave. A similar picture is documented in Europe. In $201495 \%$ of the European citizens suggest that protecting the environment is important to them personally and over three quarters feel that environmental problems have an impact on their daily lives (Eurobarometer, 2014). Furthermore, in $2011,84 \%$ of the European citizens suggest that the decision to buy a specific product is influenced by the product's impact on the environment. This again presents an increase of $6 \%$ points, when compared with that noted in 2009.

Evidently, the decision to consume is strongly and increasingly guided by the consumers' environmental awareness. The reasoning is quite straightforward: those individuals closely linking environmental degradation with the production of goods (environmentally aware individuals) are likely to consume less of these goods. Moreover, the most educated and those considering themselves to be high on the social staircase are more worried about environmental 
issues, and this places the role of social status at the heart of this debate. Ek and Söderholm (2008) and Kotchen and Moore (2007) show that environmental awareness largely influences the choice of green electricity for household use, while Hobson (2003) suggests that many of the programs aiming to affect the consumption patterns of individuals for environmental purposes have been ineffective. Thus, it would be interesting to examine whether environmental awareness affects the more general consumption of polluting goods, such as energy usage, for a general population sample.

The respective role of environmental awareness in the labor/leisure decision of individuals and households is much more under-researched even at the level of anecdotal evidence. There are two main reasons driving a potential relation between environment awareness and the labor supply decisions. First, environmentally aware households might decide to decrease their labor supply if they relate their work to the worsening of environmental conditions and associated health-related issues. Examples can be found in the working of labor unions in the USA, Europe, and Australia, even since the 1960s (e.g., Anderson and Jacobs, 1999) or the decision of the German government to shut down all nuclear plants by 2022, despite the obvious impact of this decision on output and employment. Second, environmentally-aware households might link greener employment, or the decision to actively participate in environmental movements, to social status. Thus, social status can affect the decisions of households to work less so as to free time for environmental endeavors or work less in environmentally harmful jobs.

In this study, we analyze these theoretical propositions in detail and hypothesize that the level of environmental awareness plays a role in the consumption and labor supply decisions of households. Subsequently, we empirically test these hypotheses using survey data from PSID for the year 2011 (and alternatively for 2009). The advantage of PSID is that it includes unique information at the individual or household level about the main variables used in our study. Specifically, we use information on the decision to donate for environmental purposes 
as a proxy for environmental awareness and for the annual work hours of the household's head to measure labor supply. For consumption, we mainly consider the consumption of polluting goods, which mostly include energy usage. Furthermore, to identify the labor supply and consumption equations, we control for a rich set of economic, demographic, cultural, and intellectual characteristics of the households, as well as for regional fixed effects.

Despite the use of a very rich set of control variables, identification of a causal effect of environmental awareness on the households' labor supply and consumption can still be problematic given the potential existence of reverse causality, omitted-variables issues, and the interrelationship between consumption and labor decisions of households. Thus, we complement the OLS method with instrumental variables (IV) and simultaneous equations techniques. For the IV method, we exploit the information on whether the households' heads have a medical condition associated with the quality of the environment, which, by their own statement, does not affect their everyday activities. We assume that this condition enhances their environmental awareness, but does not directly affect their leisure/labor or their consumption decisions precisely because it does not affect their everyday activities.

Quite surprisingly, the results of all the analyses show that increased environmental awareness mainly reduces the supply of labor and not so much the consumption of polluting goods. In particular, our preferred specification indicates that the environmentally aware households decrease their labor supply (household head's hours worked annually) by an economically significant $6.6 \%$, while the effect on polluting consumption is negative but not always statistically significant. These findings are in contrast to the predominant view that people who make environmental donations also choose to consume less environmentally harmful products. However, the results do support a much less investigated viewpoint of these individuals with respect to their decision to work less hours, ceteris paribus. 
Intuitively, we also find that the potency of the negative effect of environmental awareness on labor supply increases with the pollution intensity of the individuals' job, as well as when individuals adopt a more healthy life-style or are employed in the health industry. Similarly, higher individuals' income and higher education levels further enhance the negative impact of environmental awareness on labor supply. These findings pose strong indications behind the relevant channels through which environmental awareness affects the labor supply decisions of individuals.

The rest of this paper is structured as follows: Section 2 provides a review of the related literature, Section 3 discusses the empirical model and the data set, Section 4 analyzes the identification issues and discusses the empirical results, and Section 5 concludes.

\section{Mechanisms linking environmental awareness with consumption and labor decisions of households}

Our study on the effect of environmental awareness on the level of consumption and labor supply of households is broadly related to two very large, but quite independent literatures. The first is economics-based and analyzes the consumption and labor-supply habits of households. The second is broadly related to other social sciences, mainly environmental studies, and considers the role of sustainable consumption and production in human welfare from this perspective. In this section, we outline the most relevant studies in a non-exhaustive way, in an effort to formulate testable hypotheses concerning the effect of environmental awareness on the consumption and labor supply of households.

The first literature builds both on formal theoretical economic models and empirical applications. From a micro-theoretical perspective, Conrad (2005), using a micro model of consumer preferences, suggests that increasing environmental awareness negatively affects the utility of consuming a product for which a greener substitute is available. Bansal and 
Gangopadhyay (2003) study the welfare responses to environmental taxation policies and show that consumers are willing to pay more for greener products.

Similar implications are drawn from recent general equilibrium macroeconomic models, in which the environmental quality enters the household's objective function along with consumption. A seminal contribution to this literature is the study by Bovenberg and Smulders (1995), who incorporate in their model a pollution-augmenting technological change. A similar setup is used in the study by Vella, Dioikitopoulos, and Kalyvitis (2014), with their findings suggesting that environmental awareness is negatively linked to households' consumption.

The findings of the empirical literature on environmental awareness and consumption in general confirm these theoretical predictions. The most relevant studies to our analysis are those of Ek and Söderholm (2008) and Kotchen and Moore (2007), who respectively use survey data from Sweden and Michigan. These studies show that environmental awareness largely influences the choice of green electricity for household use, as does the degree of perceived personal responsibility for the issue or altruistic behavior in general.

Concerning the effect of environmental awareness on the labor/leisure decisions of households, the only directly relevant study is the theoretical one of Iosifidi and Jafarey (2013). One of the predictions of the general equilibrium model of this study is that an increase in environmental awareness (the weight that households place on environmental quality), with an associated decline in the weight of households on consumption, decreases the supply of labor. Also, a handful of empirical studies relate pollution (and not environmental awareness) to the hours of work of households (e.g., Hanna and Oliva, 2011), implying a negative relation between the two.

The second strand of the literature, mostly originating in the field of environmental studies, considers the role of environmental awareness in shaping public opinion and households' actions. A strong a priori assumption of this literature is that environmental awareness will 
reduce the consumption of polluting goods (e.g., Burgess et al., 1998). However, Hobson (2003) reviews a large qualitative literature on the potential effects of programs aiming to enhance environment in an effort to affect consumption patterns of individuals, suggesting that many of these programs can be ineffective. Thus, the extent to which environmental awareness is linked to lower consumption of polluting goods in general needs to be further formally quantified.

The environmental science literature also focuses on the relation between environmental behavior and values (e.g., Stern and Dietz, 1994; Vigar, 2000) and argues that consumption and production of certain environmentally harmful goods, such as transportation and shopping, has become a social and cultural norm related to social status. Effectively, the origins of these ideas come from the social identity theory (that dates back to Marx and Weber) and relate environmental awareness to the creation of specific identities (Pred, 1996) and consumption and employment as a form of social exclusion/inclusion (Williams et al., 2001).

Given the two strands of literature reviewed, our prediction is that environmental awareness has (if anything) a negative effect on polluting consumption of households. Identifying such a negative effect using survey data from a large-scaled sample of households and general indicators of polluting consumption would strengthen the findings by Ek and Söderholm (2008) and Kotchen and Moore (2007), who identify these effects using household survey from Sweden and Michigan, as well as the findings from studies that provide anecdotal evidence for the same relation.

Concerning the impact of environmental awareness on the labor supply, there exists no empirical analysis to back up a causal relation running from environmental awareness to labor supply decisions of individuals or households. Based on the slim theoretical literature and anecdotal evidence reviewed, our prediction mostly points to a negative effect, the reasoning being twofold. First, environmentally aware households could relate their work output to 
environmental degradation and increased health-related concerns. In turn, these households would demand more leisure time to work for environmental causes or decide to work less in environmentally harmful jobs. Examples can be found in the working of labor unions in the USA, Europe, and Australia, even since the 1960s (e.g., Anderson and Jacobs, 1999). More recently, the Fukushima nuclear disaster in 2011 considerably strengthened the segment of people opposing the use of nuclear power (BBC, 2011). The German government decided to shut down all nuclear plants by 2022, despite the obvious impact of this decision on output and employment, especially given the surging economic turmoil in the European Union during the same period. Such decisions inevitably place the role of environmental awareness in a central position within the labor-supply decisions of households and governments.

Second, the theory of social stratification posits that the nature of one's job is one of the most important identifiers of social status. With increasing environmental awareness, jobrelated social status might be increasingly linked to greener types of employment (Bullard, 1990). Similarly, evidence suggests that populations with minimal political power are generally the most vulnerable to environmental inequalities and that social stratification and environmental quality are present in the minds of urban planners, corporations, workers, and residents who often try to maximize their vested interests at the expense of others (Pellow, Weinberg, and Schnaiberg, 2001). Thus, it could be quite intuitive that environmental awareness and job-related social status of individuals go hand-in-hand in determining the employment decisions of these individuals.

We must note that, following the above reasoning, the effect of environmental awareness on the labor supply of households could also be positive if the households in fact work for environmentally-related causes or if the supply of greener forms of employment grows. Greener jobs certainly increase in numbers over time, but whether this implies that the effect of environmental awareness on labor supply can be positive on average seems questionable. 
Based on these considerations, we formulate our testable hypotheses as follows:

H1. Environmental awareness has a negative effect on the labor supply of households.

H2. Environmental awareness has a negative effect on the consumption of households, especially on the consumption of polluting goods.

\section{Empirical model and data}

The theoretical framework points to the estimation of labor-supply and consumption equations with environmental awareness as the main explanatory variable. The relevant equations are as follows:

$$
\begin{aligned}
& L_{i}^{S}=a_{0}+a_{1} E A_{i}+a_{2} X_{i}^{1}+u_{i}^{1}, \\
& C_{i}=b_{0}+b_{1} E A_{i}+b_{2} X_{i}^{2}+u_{i}^{2} .
\end{aligned}
$$

In Eq. (1), $L$ is the labor supply of household (or individual) $i, E A$ is environmental awareness, $X^{1}$ is a vector of control variables affecting labor supply, and $u^{1}$ is the stochastic disturbance of the labor supply equation. In Eq. (2), $C$ is the consumption of the polluting goods, $X^{2}$ is a vector of control variables affecting this consumption, and $u^{2}$ are the unobserved components of the consumption equation. These two equations can be estimated either as a system of equations or separately, and in the present study, we use both these approaches.

To estimate Eqs. (1) and (2), we employ cross-sectional household-level data for the USA obtained in the year 2011. Our data source is the PSID and, more specifically, the 2011 public release family file, which consists of 8907 records and 5136 variables for 51 states. This file contains one record for each family interviewed and includes all family-level variables collected in 2011, with information on a very wide range of economic, financial, demographic, behavioral, and numerous other variables. We chose to use only the 2011 data to avoid conflict with the financial crisis of 2007 , but we also examine the sensitivity of our findings to equivalent data from the 2009 file. We cannot go much earlier than 2007 (the year of the 
origination of the crisis) due to data (un)availability for some of our main variables. The definitions of the main variables used in the empirical analysis are given in Table 1 and summary statistics are presented in Table A1.

\section{[Insert Table 1 about here]}

The variable used to measure labor supply is the household's head annual total hours of work. This measure had been the preferred measure of labor supply in the relevant empirical literature (e.g., Heckman, 1993; Blundell and MaCurdy, 1998; Meghir and Phillips, 2008). Concerning polluting consumption, we use the dollar value of annual expenses for gas or electricity plus expenses for vehicle fuel. As a sensitivity test, we also examine the vehicle fuel expenditure for household heads that have to commute to work and should have access to mass transit because the households are located in metropolitan areas. These approaches are similar to that of Ferrer-i-Carbonell and van den Bergh (2004), who consider measures of energy usage, ownership of car(s) as a measure of gasoline demand, etc. In addition, we also employ a proxy for total consumption, which includes all basic consumption expenditures by households on an annual basis. ${ }^{1}$ However, we prefer using polluting consumption because environmentally aware people are more likely to reduce specifically the consumption of polluting goods.

Our explanatory variable characterizing environmental awareness is a binary variable, which takes a value equal to one if the household has donated money for environmental purposes, including organizations that preserve the environment, such as conservation efforts, animal and park protection, etc., and zero otherwise.

Following the literature on the estimation of labor-supply and consumption equations (e.g., Friedberg, 2000; Ferrer-i-Carbonell and van den Bergh, 2004), we also control for a number of

\footnotetext{
${ }^{1}$ These include the polluting expenses plus total other utilities, expenses for house repairs, car-related expenses, transportation and parking expenses, school-related expenses, medical expenses, clothing, and recreational expenses. We exclude food expenses as we consider food to be, at least partially, a more basic good that is irrelevant to environmental awareness.
} 
other basic variables. Given the rich information in the PSID, we experiment with a very large number of potential control variables, but resort to those described in the following paragraph. The reasons for our choice are that these variables seem to be directly related to some underlying theory, are usually statistically significant in our regressions, and do not present high pairwise correlation coefficients.

In general, the control variables can be categorized into three groups (for a similar classification see Ferrer-i-Carbonell and van den Bergh, 2004). First, we control for economic variables. One of the most basic factors that determine household decisions is the level of income (Blundell and Macurdy, 1999), which in our case also serves as a proxy for the wage rate. Our measure is the household's total income, which was collected in 2011 for the tax year 2010, and is calculated using the taxable, transfer, and social security income of all the family members. We prefer this approach instead of including a direct measure of the wage rate because we are not focusing on the elasticity of the labor-supply. However, we also consider a more direct proxy of the wage rate, calculated as the labor income or labor income per hour. These two measures are highly correlated to household income and, thus, we only include the total household income in the estimated equations.

Furthermore, the total wealth of households can probably have an independent effect, relative to income, on labor supply because a very wealthy household may decide to lower its working hours. Thus, we use the total household wealth (assets minus debts) plus the value of home equity. Moreover, the decision to work and consume can be influenced by whether the household owns its own house. Accordingly, we use own house, which is a dummy variable equal to one if the household owns their house and zero otherwise, and house rooms, which represents the actual number of rooms in the household's home, excluding bathrooms. The latter variable also partially controls for higher energy usage (polluting consumption) by larger 
households. Finally, mortgage is also a dummy variable, which is equal to one if the property has a mortgage or loan and zero otherwise.

The second group of determinants consists of the demographic characteristics of the households. We control for the age and the age-squared of each household's head because of the relevant nonlinearities of age in relevant empirical models suggested by the life-cycle hypothesis (Modigliani, 1966). Moreover, we control for the head's gender and marital status, as well as the number of children in each household. The latter variable also controls for the number of individuals in the household to avoid erroneously attributing high energy usage to environmental awareness in large households. ${ }^{2}$

Third, the labor supply and consumption of households are usually affected by a number of variables characterizing their quality of life. Such an obvious characteristic is the health status of individuals, with more healthy individuals being associated with higher workload and consumption (Parsons, 1977). As a proxy for the health status, we use a variable that takes values from one (excellent health) to five (poor health). Another important determinant of the labor supply and consumption patterns of individuals is their educational background (Browning and Crossley, 2001). Educated individuals usually work more hours because their expertise knowledge increases their employment chances. Consequently, more educated family members are wealthier and this can lead to higher levels of consumption. To measure education, we use the head's completed education level. Finally, certain social and emotional characteristics of individuals can affect labor supply and consumption. Two of these are the respondents' reported life satisfaction and religiosity. For the latter, we find that the significance in some of the estimated equations mainly comes from the wives' religiosity (how often the wife attends religious services within a year).

\footnotetext{
${ }^{2}$ Alternatively, we experiment with the number of individuals living in family or household units, the results being very similar.
} 


\section{Empirical identification and results}

\subsection{Environmental awareness and labor supply}

An important identification problem in estimating reduced-form equations such as Eq. (1) is distinguishing labor supply from labor demand. In our setting, the richness of the data set allows observing the labor supply at the very micro level (household heads), and this is a first safeguard against this identification problem. However, it could still be the case that the local labor demand affects the households' decisions because of economic fluctuations, specific local characteristics of the labor market, local regulatory policies, etc. These effects could also be omitted variables in the estimation of both Eqs. (1) and (2), biasing the coefficient estimates on environmental awareness.

We control for these effects by introducing interaction terms between state dummy variables and 10 dummy variables constructed from the respective categories of the Beale-Ross Rural-Urban residence code (state*Beale dummies). This residence code groups the residential areas into 10 categories, with the most urban one being the central counties of metropolitan areas comprising a population of one million or more and the completely rural one at the other end. Another merit of this approach is that these dummy variables capture the effect of other local economic and qualitative characteristics, most notably, the effect of environmental quality for which we do not include an explicit control variable. ${ }^{3}$

Table 2 reports the OLS results on the effect of environmental awareness on labor supply when the head of the family is employed. ${ }^{4}$ The table has three columns; in column I, the households' economic characteristics (household income, household wealth, own house, house

\footnotetext{
${ }^{3}$ Instead, we also experiment with explicit controls for environmental quality using data from the U.S. Environmental Protection Agency. We do not observe any significant changes in the coefficient on environmental awareness.

${ }^{4}$ We also consider the case for all household heads (both employed and unemployed). Although the results are similar, this case is somewhat meaningless for the labor-supply equation, simply because some of the individuals do not work.
} 
rooms, and mortgage) have been used as explanatory variables; in column II, the variables related to the households' demographics (age of head, gender of head, no. of children, and married head) have been added; in column III, the rest of the variables that describe the quality of life of the households (health of head, education of head, life satisfaction, and religiosity of wife) have been included.

\section{[Insert Table 2 about here]}

In all the three columns, the coefficients on environmental awareness are negative and statistically significant at the $1 \%$ level. These effects are also economically important, because they indicate that environmentally aware households are associated with a decline in the annual working hours of their head by 121.4 hours for the mean household in our sample when we use all three categories of explanatory variables in column III (the respective values for columns I and II are 134.564 and 105.068, respectively).

In line with our theoretical underpinnings, we can attribute our findings to two conjectures (channels). First, households simply decide to work less if they relate their work to environmental degradation or to general health-related issues. These individual choices create general social trends that can shift the labor supply to a lower equilibrium. Examples for this mechanism can be found in the actions of labor unions concerning environmental issues in a number of countries. ${ }^{5}$

The second reason relates to employee's social status. An environmentally aware household decides on its labor supply based, inter alia, on job satisfaction as a very important element of its well-being. However, apart from this satisfaction, the nature of job positions the households within a societal group. This idea is central in theories of social stratification and class at least since the times of Marx and Weber. In other words, as environmental awareness

\footnotetext{
${ }^{5}$ In the USA, one of the greatest supporting bodies of pollution control in the mass environmental movements as early as in the late 1960s was the labor unions, which more recently formed many alliances with environmental groups (Kojola, 2009). Similar examples can be given for other countries (e.g., Inoue, 1999).
} 
increases, the labor supply linked to environmentally harmful activities is lower because of the lower social status given to such production activities. We further examine below which of these two mechanisms is the actual driving force of the negative nexus between environmental awareness and labor supply.

With regard to the control variables, we observe that household income and house rooms are positively and significantly correlated to the labor supply. Living in a larger house creates higher expenses and requires more labor supply as a source of income. ${ }^{6}$ The coefficient of own house is also positive and statistically significant in columns II-III. This result is also intuitive: Families that own their house and live together are typically those that supply more labor. In turn, wealth bears a negative and significant coefficient, which is in line with the proposition that a lower level of wealth prompts household members to increase their labor supply. This can be especially true for younger individuals who have not accumulated wealth and perhaps have to repay tuition-related loans. Yet, even older workers with low levels of wealth can delay their retirement if pension schemes are unfavorable. In contrast, a high level of wealth works as a disincentive to increase the supply of labor.

The coefficient on age of head is positive and statistically significant, while that on age of head squared is negative and significant. This finding is in line with the life-cycle hypothesis and suggests that the impact of age on work hours is positive up to a certain age and becomes negative as individuals grow older and retire. Gender of head carries a positive and significant coefficient, implying that men work more hours than women. Furthermore, the higher the number of children, the lower is the labor supply. Married head and education of head both have a positive and significant coefficient. These findings are intuitive given the respective

\footnotetext{
${ }^{6}$ Causality can also run in the opposite direction: More hours worked earn higher incomes, which allows living in a larger house. However, identifying causality in this relation is beyond the scope of the present analysis.
} 
selection mechanisms: the head needs to work more to financially sustain the household, while educated individuals can find jobs more easily.

With regard to variables characterizing the quality of life of households, life satisfaction has a negative and statistically significant coefficient, implying that the more the head of the family is satisfied with his/her life, the higher is his/her labor supply. This finding is in line with those reported by Alesina, Glaeser, and Sacerdote (2006), who show that people who are more balanced in their approach to life are happier. Finally, health of head and religiosity of wife are insignificant determinants of labor supply in our sample.

\subsection{Endogeneity issues in the labor-supply equation}

So far, we have essentially assumed that environmental awareness is an exogenous determinant of the labor-supply decisions of households if we control for certain household characteristics and state*Beale fixed effects. However, causality may run in the opposite direction owing to the potential effect of labor supply on environmental awareness. For example, individuals with jobs in polluting industries can be more environmentally aware. In addition, irrespective of the state*Beale dummies, there could be other household or individual characteristics (omitted variables) affecting the relation between environmental awareness and labor supply. This is an important problem because unobserved household or individual characteristics could be erroneously captured by the propensity of individuals to make environmental donations.

To rule out any other source of endogeneity using the two-stage least squares (2SLS) model introduced by Lewbel (2012). This approach may be applied when no external instruments are available or, as in our case, to supplement external instruments so as to improve the efficiency of the usual 2SLS estimator. Lewbel's method exploits the relationship between heteroskedastic error variances and exogenous regressors to achieve identification. Thus, it

relies on two conditions. First, the error term from the first-stage regression, $\varepsilon_{i}^{j}$, should be 
heteroskedastic, with $j=1,2$, where 1 indicates labor supply and 2 denotes polluting consumption. Second, there exists a vector of variables $Z_{i} \subseteq X_{i}$ satisfying the following condition:

$$
\operatorname{Cov}\left(Z_{i}, \mathrm{u}_{i} \varepsilon_{i}\right)=0
$$

We test these conditions and we find that both are satisfied.

Accordingly, in the first-stage regression, the endogenous variable environmental awareness is regressed on $X$ and we obtain the estimated residuals $\hat{\varepsilon}_{i}$. The reduced-form residuals are then multiplied with each of the included exogenous variables in mean-centered form:

$$
\left(Z_{i}-\bar{Z}\right) \hat{\varepsilon}_{i}
$$

where $\bar{Z}$ is the mean of $Z_{i}$. Then, in the second stage, these constructed instruments are used in Eq. (1).

We use Lewbel's method with and without external instruments, and we present the results from the former case as the differences are minimal. The external instrumental variable, named environmental disease, is a dummy variable equal to one if the head of the household has or ever had a chronic lung disease or cancer, while these diseases never affected his/her everyday life until the time of the survey, and zero otherwise. We only use lung diseases and cancer from a variety of other health problems because these are more directly related to environmental quality in the residential area of the household. Thus, we assume that individuals who have ever suffered from these diseases place a higher weight on environmental quality (e.g., air and water quality). We assign a variable equal to one only for individuals whose everyday life was never affected because, otherwise, it would be very likely that the labor supply of the affected individuals would be lower and the exclusion restriction would not be satisfied. Our data set contains this explicit information because individuals are specifically asked about whether the disease affected their everyday life. Given that working is one of the most important elements 
of everyday life, we feel that the instrumental variable in its restricted form does not have a direct effect on the household head's labor supply.

On comparing the coefficients derived using the method of Lewbel (Table 3) with those from the OLS model (Table 2), we observe that the estimation results are almost the same. More specifically, in all the three columns, the coefficients of environmental awareness are negative and statistically significant. The negative effect is still economically significant because, based on the more restrictive specification of column III, it indicates that the heads of environmentally aware households work 98 hours less per year or a $6.6 \%$ reduction for the household head with the mean annual work hours $(1,490.6 \text { hours })^{7}$

[Insert Table 3 about here]

\subsection{Testing for the channels of the effect of environmental awareness on labor supply}

In this section we provide more direct tests for the channels through which environmental awareness affect the labor supply decisions of individuals, as discussed in Sections 2 and Section 4.1. In Table 4 we report results due to the level of pollution generated by the head's main occupation. The intuition behind this test is to explore the possibility that our main result obtained so far is higher for (or is mostly attributed to) those who are employed in the more heavily polluting industries. To test this conjecture, we use the following equation:

$$
L_{i}^{S}=a_{0}+a_{1} E A_{i}+a_{2} X_{i}+a_{3} E A_{i} * P I_{i}+a_{4} P I_{i}+u_{i}^{1},
$$

where $P I$ is the pollution intensity of industry $i$.

To measure $P I$ we use data from Levinson (2009), who constructs pollution-intensity indicators across a large number of industries. ${ }^{8}$ Specifically, we match the sic industry codes

\footnotetext{
${ }^{7}$ We also use a standard 2SLS procedure with only environmental disease as an instrument. The coefficients derived using this method are the same in terms of statistical significance, but the standard errors are higher, implying that the use of Lewbel's method reduces bias at least in our sample. Moreover, as our endogenous variable is binary, we can theoretically improve the efficiency of the estimates using the treatment effects IV model. The results remain almost the same in terms of statistical significance.

${ }^{8}$ A very similar methodology is also used by Broner et al. (2013).
} 
in the data set of Levinson with the industries in the PSID data and calculate three industryspecific pollution indicators for toxics to air, water, and land, respectively. Subsequently, we use these three indicators (named pollution intensity of job) in turn to estimate equation (5). To directly interpret the coefficient on environmental awareness at the average level of each PI, rather than at the point where each $P I$ is zero, we mean-center the variables used to construct the interaction terms.

We find that the coefficients on environmental awareness in all three specifications lose some (but not much) of their economic significance, which is absorbed by the interaction term between environmental awareness and pollution intensity of job. We interpret this result as evidence that the channel working through the individual's preference to work less when the job is polluting is potent (given that the interaction term is significant) but it is not the sole channel (given that the main effect is still significant). We further experiment with three equivalent indicators of metals (instead of toxics) to air, water and land, the results being qualitatively similar.

\section{[Insert Table 4 about here]}

To further analyze the sources of the positive nexus between environmental awareness and labor supply, we introduce the dummy variable non-smoker that takes the value one if the household's head does not smoke and zero if he/she smokes, as an indicator of the propensity of these individuals to value being in good health. ${ }^{9}$ We expect that if the argument holds that individuals are adverse to environmental degradation due to health-related issues, then the impact of environmental awareness should be higher for those individuals that do not smoke (i.e., the coefficient on the interaction term between non-smoker and environmental awareness

\footnotetext{
${ }^{9}$ The correlation coefficient between smoke and environmental awareness is positive (0.072) and statistically significant at the $1 \%$ level, indicating that people who do not smoke also have a higher probability to make environmental donations.
} 
should be negative and significant). We do not use this interaction term in the regressions of Table 4 due to multicollinearity concerns.

We report the results from this exercise in columns I and II of Table 5, respectively. Evidently, the negative effect of environmental awareness on the labor supply is stronger for individuals that do not smoke or for individuals that are employed in the health industry. These results indicate the potency of the health-related channel of the environmental awareness-labor supply nexus. ${ }^{10}$ Further, the fact that the main term of environmental awareness loses part (but not all) of its statistical significance (and this is taken by the interaction term) precisely implies that the health-related channel is at work but is not the sole channel.

Moreover, we introduce similar interaction terms with measures of social status, namely the level of income and education. ${ }^{11}$ Our hypothesis is that the negative effect of environmental awareness on the labor supply is channeled through the socioeconomic status of individuals (here household heads). Our results, reported in columns III and IV of Table 5, are quite similar to the ones for those reported in Table 4 and those for the health-related channel. Again, the coefficient estimates on environmental awareness lose some ground in terms of significance (the estimates fall relative to the equivalent ones in column III of Table 3 and are statistically significant only at the 10 level) and this significance is transferred to the interaction terms with household income and education of head. Both these interaction terms are statistically significant at the $5 \%$ level, indicating that the impact of environmental awareness is partially channeled through the status-related variables.

[Insert Table 5 about here]

\footnotetext{
${ }^{10}$ Of course, many other such variables reflecting the health preferences or health-related knowledge of individuals could be used in interaction terms with environmental awareness. Our premise here is to reflect the potency of this channel and not to be exhaustive with respect to such variables.

${ }^{11}$ The literature on the measurement of social status (or class) proposes a variety of measures. Here we use socalled "objective" indicators employed in the socioeconomic studies (see e.g., Diemer, 2013; references therein).
} 


\subsection{Environmental awareness and polluting consumption}

In this section, we consider the effect of environmental awareness on polluting consumption. Given that all households consume, we report in Table 6 the OLS results for all available observations (both employed and unemployed heads). Similar to those presented earlier, in column I, the households' economic characteristics are used as explanatory variables; in column II, the variables related to the households' demographics are added; and in column III, the rest of the variables that describe the quality of life for the households are included. All the specifications include state*Beale fixed effects.

\section{[Insert Table 6 about here]}

In all the columns, the coefficients on environmental awareness are negative and statistically significant at conventional levels. These effects are also economically significant. Based on the results of column III, it is observed that environmentally aware households consume $\$ 209.6$ less of the polluting goods, which is an effect equivalent to a $7.5 \%$ reduction. Similar to the labor-supply equation, the effect of all the control variables is in line with our prior expectations.

Table 7 presents the effect of environmental awareness on polluting consumption only for the employed heads. This sensitivity analysis was conducted for two reasons. First, the families with unemployed heads will consume less because of their lower income. Second, we conduct this analysis for the sake of symmetry with the labor-supply equations, which will also allow regressing the labor supply and consumption equations as a system (this is further discussed in Subsection 4.5). Evidently, the estimation results are almost the same as those given in Table 6 , except that the variables describing the quality of life for the households are statistically insignificant. Thus, it now remains to be examined whether this effect prevails in the IV regressions.

[Insert Table 7 about here] 


\subsection{Endogeneity issues in the consumption equation}

There are a number of endogeneity concerns associated with analyzing the effect of environmental awareness on polluting consumption decisions of the households. The first one is the existence of reverse causality. For example, individuals who consume more polluting goods are exposed to hazardous chemicals and, thus, become more environmentally aware. The second, and similar to the case of labor supply, is that there could be other variables that affect the relation between environmental awareness and polluting consumption and are not included in the regression. These endogeneity issues, if not treated could lead to biased and inconsistent estimates, and invalid inference.

To deal with these issues, we follow a strategy similar to the labor-supply regressions. First, we employ the 2SLS of Lewbel (2012) with the results reported in Table 8 . In all the three columns, the coefficients on environmental awareness are negative, but only in column I, the coefficient is statistically significant. These findings show that when the demographic characteristics of the household are controlled for, consumption does not significantly respond to environmental awareness. Thus, in this case, the OLS results are not confirmed because the effect of environmental awareness on polluting consumption is less robust, when compared with the case of labor supply.

[Insert Table 8 about here]

Further, similar to the regressions presented in Table 4, we estimate the following equation:

$$
C_{i}=b_{0}+b_{1} E A_{i}+b_{2} Z_{i}+b_{3} E A_{i} * P I_{i}+b_{4} P I_{i}+u_{i}^{2}
$$

Just as in the rest of the consumption equations, we do not find a significant effect on the main term of environmental awareness, while the estimates on the interaction terms are also insignificant. The results are very similar if we replicate the analysis of Table 5. As our results 
in Table 7 do not show a particularly potent effect of environmental awareness on consumption, it is quite intuitive that the channels characterized by the interaction terms are not potent either.

[Insert Table 9 about here]

\subsection{Simultaneity in the labor supply and consumption equations}

In this section, we examine the case of simultaneity between labor supply and consumption, as households would likely make these decisions dependent on one another. Theoretically, the premise is either that individuals might choose to work less to have more time to consider their consumption behavior or that individuals choose to consume less because they prefer to work less. If these choices are erroneously captured by our environmental awareness variable, our results presented so far would be biased. We approach this issue in two ways. First, we control for polluting consumption in Eq. (1) and labor supply in Eq. (2). The results (available on request) show that the coefficient estimates and statistical significance of environmental awareness are essentially the same as those presented earlier.

The second approach is to estimate the simultaneous equation model for Eqs. (1) and (2) using the Full Information Maximum Likelihood (FIML) method. The estimation results are presented in Table A2. To identify the model, we place some restrictions in terms of differentiating the explanatory variables of the two equations. As previous specifications revealed that the variables characterizing the quality of life of households' heads are statistically insignificant in all the polluting-consumption equations, we exclude them from Eq. (2). Again, in the labor-supply equation, the environmental awareness is negative and statistically significant at $1 \%$ level. Environmentally aware households work 121.07 hours less, which is equivalent to an $8.1 \%$ decrease. In the polluting-consumption equation, the effect of environmental quality is statistically significant, but only at $10 \%$ level. Environmentally aware households spend $\$ 193.206$ less in polluting goods, which is equivalent to a 5\% decrease. 


\subsection{Other sensitivity tests}

In this section, we provide further robustness tests concerning our measures of environmental awareness and polluting consumption. First, we examine whether our environmental awareness variable captures the propensity of households to make donations in general. To this end, we construct another dummy variable called other donations, which takes a value one when households make any donations other than those for the environment and zero otherwise. We include this variable in the last two regressions in Table A2 for the labor-supply and consumption equations, respectively. We find that the coefficients on environmental awareness remain essentially unchanged, while donations have a positive and significant coefficient in both the regressions. This implies that people who care and donate in general choose to work more, whereas people who care and donate about the environment in particular choose to work less. In addition, this finding also strengthens our point that the environmental donations variable captures something unique and specific to environmental awareness of households and not anything that relates to the sympathetic nature of people in general, or their propensity to work less.

Second, we use a more restrictive measure of polluting consumption. Specifically, we restrict our sample only to households located in metropolitan areas that have to commute to work and examine the impact of environmental awareness on expenses for car gasoline. We assume that these households should have access to mass transit, which is environmentally friendlier. We again base our analysis on the equivalent model of column III of Table 7, and this yields a coefficient estimate on environmental awareness equal to -107.55 (t-stat is -0.77 ). Thus, the more restrictive the model in terms of the measure of polluting consumption, the lower the statistical and economic significance of environmental awareness in explaining polluting consumption. 
Third, we explore the possibility that our results are driven by the selection of the 2011 wave and we re-estimate our preferred specifications of column III in Tables 3 and 8 using data from the year 2009. We report these results in Table 10. Evidently, the results are not much affected by the year of study, with environmental awareness bearing a significant effect mostly in the labor supply equation (column I).

[Insert Table 10 about here]

\section{Conclusions}

The present study empirically analyses for the first time the effect of environmental awareness on the labor-supply and consumption decisions of the households. We use a large sample with household survey data and estimate labor-supply and polluting-consumption equations using OLS, instrumental variables, and simultaneous-equations regressions. Our evidence suggests that environmentally aware households decrease labor supply, which is a statistically and economically significant finding in all the estimated specifications. More specifically, according to our preferred specification, environmentally aware households decrease their labor supply by $6.6 \%$. In addition, we also find a negative effect of environmental awareness on consumption, but this effect is not as robust in terms of statistical significance.

The results obtained in this study have important implications for researchers and policy makers alike. The finding that an increase in environmental awareness for the average representative household does not significantly affect the consumption of polluting goods goes against the very premise of the large literature that considers environmental education toward polluting goods as the single most important element in promoting a sustainable environment. Thus, although our results are driven from a more quantitative and structural analysis, they are in line with the literature that criticizes the social-marketing and "nudge"-theory approach of 
increasing individuals' environmental awareness as a means to promote greener consumption (e.g., Crompton and Thøgersen, 2009; Thaler and Sunstein, 2008; Barr and Prillwitz, 2014).

In contrast, our results confirm a more pragmatic approach to the issue of environmental awareness that relates to labor supply. This issue has only been examined by a scant macroeconomics literature and our results show that higher environmental awareness decreases the hours of work, irrespective of the income and wealth of the households and other control variables. This finding is in line with the premise that environmentally aware households (i) relate their work to environmental degradation and seek to free time to benefit from a clean environment or even promote environmental goals and/or (ii) benefit from a greener job status. Identifying the dominant reason remains an empirical question until more specific data can be made available.

Furthermore, our results highlight the importance of understanding the micro foundations of household behavior related to environmental awareness and open up a path for further empirical analysis on this issue. Specifically, the interrelationship between environmental awareness and environmental taxation has not been thoroughly examined by relevant empirical literature, especially from a business/management perspective. In addition, the very drivers of environmental awareness need to be more formally quantified and specific ways through which the environmental awareness-polluting consumption nexus can be strengthened need to be reconsidered. We leave these ideas as a desideratum for future research.

\section{References}

Alesina, A., F., Glaeser, E., L., Sacerdote, B., 2006. Work and leisure in the U.S. and Europe: Why so different? NBER Macroeconomics Annual 20, MIT Press.

Anderson, K., Jacobs, J.M., 1999. Geographies of publicity and privacy: Residential activism in Sydney in the 1970s. Environment and Planning A 31, 1017-1030. 
Andreski, P., Li, G., Samancioglu, M.Z., Schoeni, R., 2014. Estimates of annual consumption expenditures and its major components in the PSID in comparison to the CE. American Economic Review 104, 132-135.

Bansal, S., Gangopadhyay, S., 2003. Tax/subsidy policies in the presence of environmentally aware consumers. Journal of Environmental Economics and Management 45, 333-355.

Barr, S., Prillwitz, J., 2014. A smarter choice? Exploring the behaviour change agenda for environmentally sustainable mobility. Environment and Planning C: Government and Policy 32, 1-19.

BBC, 2011. Germany: Nuclear power plants to close by 2022. Available at: http://www.bbc.co.uk/news/world-europe-13592208.

Blundell, R., MaCurdy, T., 1999. Labor supply: A review of alternative approaches. Handbook of Labor Economics, 1st edition, Volume 3, Chapter 27, Elsevier.

Bovenberg, A., Smulders, S., 1995. Environmental quality and pollution-augmenting technological change in a two-sector endogenous growth model. Journal of Public Economics 57, 369-391.

Browning, M., Crossley, T.F., 2001. The life-cycle model of consumption and saving. Journal of Economic Perspectives 15, 3-22.

Bullard, R.D., 1990. Dumping in Dixie: Race, class, and environmental quality. Boulder, CO: Westview.

Burgess, J., Harrison, C., Filius, P., 1998. Environmental communication and the cultural politics of environmental citizenship. Environment and Planning A, 30, 1445-1460.

Conrad, K., 2005. Price competition and product differentiation when consumers care for the environment. Environmental and Resource Economics 31, 1-19.

Crompton, T., Thøgersen, J., 2009. Simple and painless? The limitations of spillover in environmental campaigning. WWF, London, UK.

Diemer, M.A., Mistry, R.S., Wadsworth, M.E., Lopez, I., Reimers, F., 2013.

Doni, N., Ricchiuti, G., 2013. Market equilibrium in the presence of green consumers and responsible firms: A comparative statics analysis. Resource and Energy Economics 35, 380-395. 
Ek, K., Söderholm, P., 2008. Norms and economic motivation in the Swedish green electricity market. Ecological Economics 68, 169-182.

Eurobarometer, 2011. Attitudes of European citizens towards the environment. Special Eurobarometer 365, EC.

Eurobarometer, 2014. Attitudes of European citizens towards the environment. Special Eurobarometer 416, EC.

Fernandez-Villaverde, J., Krueger, D., 2007. Consumption over the life cycle: Facts from consumer expenditure survey data. Review of Economics and Statistics 89, 552-565.

Ferrer-i-Carbonell, A., Van Den Bergh, J.C.J.M., 2004. A micro-econometric analysis of determinants of unsustainable consumption in The Netherlands. Environmental and Resource Economics 27, 367-389.

Friedberg, L., 2000. The labor supply effects of the social security earnings test. Review of Economics and Statistics 82, 48-63.

Hanna, R., Oliva, P., 2011. The effect of pollution on labor supply: Evidence from a natural experiment in Mexico City. NBER Working Paper 17302.

Heckman, J.J., 1993. What has been learned about labor supply in the past twenty years? American Economic Review, Papers and Proceedings 83, 116-121.

Hobson, K., 2003. Thinking habits into action: The role of knowledge and process in questioning household consumption practices. Local Environment 8, 95-112.

Iosifidi, M., Jafarey, 2013. The role of taxation in a Ramsey model with environmental externalities. Mimeo.

Inoue, S., 1999. Japanese trade unions and their future: Opportunities and challenges in an era of globalization. Discussion paper No. DP/106/1999, Rengo Institute for Advancement of Living Standards, Tokyo, Japan.

Kojola, E., 2009. Trade unions and green jobs in the post-Fordist economy: Just rhetoric or a fundamental shift? Available at: http://etd.ohiolink.edu/view.cgi?acc_num=oberlin12419 $\underline{06474 .}$ 
Kotchen, M.J., Moore, M.R., 2007. Private provision of environmental public goods: Household participation in green-electricity programs. Journal of Environmental Economics and Management 53, 1-16.

Lewbel, A., 2012. Using heteroskedasticity to identify and estimate mismeasured and endogenous regressor models. Journal of Business and Economic Statistics 30, 67-80.

Meghir, C., Phillips, D., 2008. Labour supply and taxes. Institute for Fiscal Studies Working Paper No. WP08/04.

Modigliani, F., 1966. The life-cycle hypothesis of saving, the demand for wealth and the supply of capital. Social Research 33, 160-217.

Parsons, D.O., 1977. Health, family structure, and labor supply. American Economic Review 67, 703-712.

Pellow, D.N., Weinberg, A., Schnaiberg, A., 2001. The environmental justice movement: Equitable allocation of the costs and benefits of environmental management outcomes. Social Justice Research 14, 423-439.

Pred, A., 1996. Interfusions: Consumption, identity and the practices and power relations of everyday life. Environment and Planning A 28, 11-24.

Stern, P.C., Dietz, T., 1994. The value basis of environmental concern. Journal of Social Issues $50,65-84$

Thaler, R.H., Sunstein, C.R., 2008. Nudge: Improving Decisions about Health, Wealth and Happiness. Yale University Press, New Haven, CT.

UN, 1992. Sustainable Development: Agenda 21. United Nations Conference on Environment \& Development, Rio de Janerio, Brazil.

Vella, E., Dioikitopoulos, E., Kalyvitis, S., 2014. Green spending reforms, growth and welfare with endogenous subjective discounting. Macroeconomic Dynamics, forthcoming.

Vigar, G., 2000. 'Barriers' to environmentally sustainable transport planning. Local Environment 5, 19-33. 
Williams, P., Hubbard, P., Clark, D., Berkeley, N., 2001. Consumption, exclusion and emotion: The social geographies of shopping. Social and Cultural Geography 2, 203-220. 
Table 1

Variable definitions

\begin{tabular}{|c|c|}
\hline Variable & Definition \\
\hline Labor supply & Household's head annual total hours of work. \\
\hline Polluting consumption & $\begin{array}{l}\text { Expenses (\$ value) for gas/ electricity plus expenses for vehicle fuel (not } \\
\text { including air travel). }\end{array}$ \\
\hline Environmental awareness & $\begin{array}{l}\text { Dummy variable equal to one if the household has donated money for } \\
\text { environmental purposes and zero otherwise. }\end{array}$ \\
\hline Household income & Total household income in 2010. \\
\hline Household wealth & Total household wealth (assets minus debts) plus the value of home equity. \\
\hline Own house & $\begin{array}{l}\text { Dummy variable equal to one if the household owns their house and zero } \\
\text { otherwise. }\end{array}$ \\
\hline House rooms & Actual number of rooms in household's home excluding bathrooms. \\
\hline Mortgage & $\begin{array}{l}\text { Dummy variable equal to one if the property has a mortgage or loan and } \\
\text { zero otherwise. }\end{array}$ \\
\hline Age of head & The age of the household's head. \\
\hline Gender of head & The gender of the household's head. \\
\hline No. of children & Number of children in the household. \\
\hline Married head & Dummy variable equal to one if the head is married and zero otherwise. \\
\hline Health of head & The health status of head, taking values from one (excellent) to five (poor). \\
\hline Education of head & $\begin{array}{l}\text { Head's completed education level. Values in the range } 1-16 \text { represent the } \\
\text { actual grade of school completed, with values } 13-16 \text { representing college } \\
\text { education. A code value of } 17 \text { indicates that the head completed at least } \\
\text { some postgraduate work. }\end{array}$ \\
\hline Life satisfaction & $\begin{array}{l}\text { The level of life satisfaction of the head, taking values from one } \\
\text { (completely satisfied) to five (not at all satisfied). }\end{array}$ \\
\hline Religiosity of wife & How often the wife attends religious services within one year. \\
\hline Pollution intensity of job & $\begin{array}{l}\text { The pollution intensity of each household head's job calculated using the } \\
\text { data set of Levinson ( } 2009 \text {. Specifically, we match the sic industry codes } \\
\text { with the industries in the PSID and calculate three industry-specific } \\
\text { pollution indicators for toxics to air, water, and land, respectively. } \\
\text { Subsequently, we use these three indicators separately. We also construct } \\
\text { equivalent indicators for metals. }\end{array}$ \\
\hline Non-smoker & $\begin{array}{l}\text { A dummy variable taking the value zero when the household's head smokes } \\
\text { and zero if he/she does not smoke. }\end{array}$ \\
\hline Employed in health & $\begin{array}{l}\text { A dummy variable taking the value one when the household's head is } \\
\text { employed in the health industry and zero otherwise. }\end{array}$ \\
\hline Environmental disease & $\begin{array}{l}\text { Dummy variable equal to one (and zero otherwise) if the head has or ever } \\
\text { had a chronic lung disease or cancer but declares that this does not affect } \\
\text { his everyday activities. }\end{array}$ \\
\hline
\end{tabular}


Table 2

Environmental awareness and labor supply for the employed

\begin{tabular}{|c|c|c|c|}
\hline & $\mathrm{I}$ & II & III \\
\hline Environmental awareness & $\begin{array}{l}-134.564 * * * \\
(-3.695)\end{array}$ & $\begin{array}{l}-105.068 * * * \\
(-2.976)\end{array}$ & $\begin{array}{l}-121.417 * * * \\
(-3.301)\end{array}$ \\
\hline Household income & $\begin{array}{l}0.001 * * * \\
(5.363)\end{array}$ & $\begin{array}{l}0.001 * * * \\
(4.609)\end{array}$ & $\begin{array}{l}0.001 * * * \\
(4.080)\end{array}$ \\
\hline Household wealth & $\begin{array}{l}-0.000 * * * \\
(-3.753)\end{array}$ & $\begin{array}{l}-0.000 * * \\
(-2.142)\end{array}$ & $\begin{array}{l}-0.000 * * \\
(-2.209)\end{array}$ \\
\hline Own house & $\begin{array}{l}69.602 \\
(1.627)\end{array}$ & $\begin{array}{l}82.411 * * \\
(2.133)\end{array}$ & $\begin{array}{l}71.226^{*} \\
(1.798)\end{array}$ \\
\hline House rooms & $\begin{array}{l}26.588 * * * \\
(4.822)\end{array}$ & $\begin{array}{l}20.386 * * * \\
(3.695)\end{array}$ & $\begin{array}{l}19.145 * * * \\
(3.372)\end{array}$ \\
\hline Mortgage & $\begin{array}{l}46.459 \\
(0.994)\end{array}$ & $\begin{array}{l}-2.219 \\
(-0.058)\end{array}$ & $\begin{array}{l}-7.344 \\
(-0.190)\end{array}$ \\
\hline Age of head & & $\begin{array}{l}55.497 * * * \\
(10.083)\end{array}$ & $\begin{array}{l}57.302 * * * \\
(10.038)\end{array}$ \\
\hline Age of head squared & & $\begin{array}{l}-0.685 * * * \\
(-10.976)\end{array}$ & $\begin{array}{l}-0.695 * * * \\
(-10.745)\end{array}$ \\
\hline Gender of head & & $\begin{array}{l}147.966 * * * \\
(4.506)\end{array}$ & $\begin{array}{l}152.728 * * * \\
(4.571)\end{array}$ \\
\hline No. of children & & $\begin{array}{l}-31.283 * * * \\
(-3.410)\end{array}$ & $\begin{array}{l}-30.915 * * * \\
(-3.200)\end{array}$ \\
\hline Married head & & $\begin{array}{l}67.868 * * \\
(2.088)\end{array}$ & $\begin{array}{l}60.375 * \\
(1.772)\end{array}$ \\
\hline Health of head & & & $\begin{array}{l}-19.624 \\
(-1.624)\end{array}$ \\
\hline Education of head & & & $\begin{array}{l}10.188 * * \\
(2.139)\end{array}$ \\
\hline Life satisfaction & & & $\begin{array}{l}-27.062 * * \\
(-2.112)\end{array}$ \\
\hline Religiosity of wife & & & $\begin{array}{l}-0.090 \\
(-0.351) \\
\end{array}$ \\
\hline Observations & 5,860 & 5,859 & 5,530 \\
\hline R-squared & 0.068 & 0.105 & 0.108 \\
\hline
\end{tabular}

Notes: The table reports coefficients and t-statistics (in parentheses) from the estimation of the labor supply equation only for the household heads that are employed. Dependent variable is the hours of labor provided by the head of the household. All variables are defined in Table 1. All three specifications include state dummies. Estimation method is OLS with robust standard errors. The $* * *, * *$, and $*$ marks denote statistical significance at the 1,5 and $10 \%$ level, respectively. 
Table 3

Environmental awareness and labor supply for the employed: IV regressions

\begin{tabular}{|c|c|c|c|}
\hline \multirow{2}{*}{ Environmental awareness } & $\mathrm{I}$ & II & III \\
\hline & $\begin{array}{l}-131.386 * * * \\
(-2.907)\end{array}$ & $\begin{array}{l}-108.429 * * * \\
(-2.622)\end{array}$ & $\begin{array}{l}-98.141 * * \\
(-2.463)\end{array}$ \\
\hline Household income & $\begin{array}{l}0.001 * * * \\
(5.380)\end{array}$ & $\begin{array}{l}0.001 * * * \\
(4.635)\end{array}$ & $\begin{array}{l}0.001 * * * \\
(4.084)\end{array}$ \\
\hline Household wealth & $\begin{array}{l}-0.000 * * * \\
(-3.780)\end{array}$ & $\begin{array}{l}-0.000 * * \\
(-2.152)\end{array}$ & $\begin{array}{l}-0.000 * * \\
(-2.241)\end{array}$ \\
\hline Own house & $\begin{array}{l}69.506 \\
(1.632)\end{array}$ & $\begin{array}{l}82.449 * * \\
(2.145)\end{array}$ & $\begin{array}{l}70.950 * \\
(1.802)\end{array}$ \\
\hline House rooms & $\begin{array}{l}26.577 * * * \\
(4.846)\end{array}$ & $\begin{array}{l}20.400 * * * \\
(3.719)\end{array}$ & $\begin{array}{l}19.080 * * * \\
(3.380)\end{array}$ \\
\hline Mortgage & $\begin{array}{l}46.482 \\
(0.999)\end{array}$ & $\begin{array}{l}-2.213 \\
(-0.058)\end{array}$ & $\begin{array}{l}-7.279 \\
(-0.190)\end{array}$ \\
\hline Age of head & & $\begin{array}{l}55.484 * * * \\
(10.133)\end{array}$ & $\begin{array}{l}57.364 * * * \\
(10.111)\end{array}$ \\
\hline Age of head squared & & $\begin{array}{l}-0.685 * * * \\
(-11.028)\end{array}$ & $\begin{array}{l}-0.697 * * * \\
(-10.828)\end{array}$ \\
\hline Gender of head & & $\begin{array}{l}147.900 * * * \\
(4.529)\end{array}$ & $\begin{array}{l}153.064 * * * \\
(4.611)\end{array}$ \\
\hline No. of children & & $\begin{array}{l}-31.324 * * * \\
(-3.433)\end{array}$ & $\begin{array}{l}-30.738 * * * \\
(-3.201)\end{array}$ \\
\hline Married head & & $\begin{array}{l}67.934 * * \\
(2.101)\end{array}$ & $\begin{array}{l}59.723 * \\
(1.763)\end{array}$ \\
\hline Health of head & & & $\begin{array}{l}-19.476 \\
(-1.620)\end{array}$ \\
\hline Education of head & & & $\begin{array}{l}9.948 * * \\
(2.098)\end{array}$ \\
\hline Life satisfaction & & & $\begin{array}{l}-27.135^{* *} \\
(-2.130)\end{array}$ \\
\hline Religiosity of wife & & & $\begin{array}{l}-0.086 \\
(-0.337)\end{array}$ \\
\hline \multicolumn{4}{|l|}{ First stage } \\
\hline Environmental disease & $\begin{array}{l}0.024 * * * \\
(2.63)\end{array}$ & $\begin{array}{l}0.019 * * \\
(2.11)\end{array}$ & $\begin{array}{l}0.018 * * \\
(2.07)\end{array}$ \\
\hline Observations & 5,860 & 5,859 & 5,530 \\
\hline UIT & 0.000 & 0.000 & 0.000 \\
\hline WIT with critical value & $30.251(11.07)$ & $44.690(11.03)$ & $69.913(11.01)$ \\
\hline OIT & 0.434 & 0.287 & 0.250 \\
\hline
\end{tabular}

Notes: The table reports coefficients and t-statistics (in parentheses) from the estimation of the labor supply equation. Dependent variable is the hours of labor provided by the head of the household. All variables are defined in Table 1. Estimation method is two-stage least squares with robust standard errors, where the first stage includes instruments constructed using the method of Lewbel (2012) and environmental disease. UIT is the p-value of the under-identification LM test by Kleibergen and Paap, which requires a values lower than 0.05 to reject the null hypothesis at the 5\% level. WIT is the Wald $F$-statistic of the weak identification test by Kleibergen and Paap, which must be higher than its critical value to reject the null. OIT is the p-value of the over-identification test by Hansen, which requires a value higher than 0.05 to reject the null hypothesis at the $5 \%$ level. The $* * *, * *$ and $*$ denote statistical significance at the 1,5 and $10 \%$ level, respectively. 
Table 4

Environmental awareness and labor supply for the employed: The impact of being employed in a polluting job

\begin{tabular}{llll}
\hline & I & II & III \\
\hline Environmental awareness & $-84.403^{*}$ & $-86.702^{*}$ & $-85.811^{*}$ \\
& $(-1.862)$ & $(-1.915)$ & $(-1.880)$ \\
Pollution intensity of job & 17.320 & 14.532 & 21.630 \\
& $(0.480)$ & $(0.338)$ & $(0.623)$ \\
Environmental awareness* & $-33.284^{* *}$ & $-28.544^{* *}$ & $-27.810^{* *}$ \\
Pollution intensity of job & $(-2.423)$ & $(-2.322)$ & $(2.262)$ \\
\hline Observations & 5,530 & 5,530 & 5,530 \\
UIT & 0.000 & 0.000 & 0.000 \\
WIT with critical value & $275.80(11.00)$ & $286.24(11.00)$ & $262.17(11.00)$ \\
OIT & 0.141 & 0.135 & 0.146 \\
\hline
\end{tabular}

Notes: The table reports coefficients and t-statistics (in parentheses) from the estimation of the labor supply equation. Dependent variable is the hours of labor provided by the head of the household and all regressions include the control variables of equation III of Table 3, which are omitted due to space considerations. All variables are defined in Table 1. Estimation method is two-stage least squares with robust standard errors, where the first stage includes instruments constructed using the method of Lewbel (2012) and environmental disease. UIT is the p-value of the under-identification LM test by Kleibergen and Paap, which requires a values lower than 0.05 to reject the null hypothesis at the 5\% level. WIT is the Wald $F$-statistic of the weak identification test by Kleibergen and Paap, which must be higher than its critical value (in parenthesis) to reject the null. OIT is the p-value of the over-identification test by Hansen, which requires a value higher than 0.05 to reject the null hypothesis at the $5 \%$ level. The ***, $* *$ and $*$ marks denote statistical significance at the 1,5 and $10 \%$ level, respectively. 
Table 5

Environmental awareness and labor supply for the employed: Identifying the sources of the nexus

\begin{tabular}{|c|c|c|c|c|}
\hline & $\mathrm{I}$ & II & III & IV \\
\hline \multirow[t]{2}{*}{ Environmental awareness } & $-82.48 *$ & $-88.314^{*}$ & $-75.221 *$ & $-71.103 *$ \\
\hline & $(-1.841)$ & $(-1.948)$ & $(-1.803)$ & $(-1.744)$ \\
\hline \multirow[t]{2}{*}{ Non-smoker } & $53.571^{*}$ & & & \\
\hline & $(1.959)$ & & & \\
\hline Environmental awareness* & $-126.24 * *$ & & & \\
\hline Non-smoker & $(-2.277)$ & & & \\
\hline \multirow{2}{*}{ Employed in health } & & $71.915 * *$ & & \\
\hline & & $(2.120)$ & & \\
\hline Environmental & & $-203.91 * *$ & & \\
\hline awareness*employed in health & & $(-1.988)$ & & \\
\hline \multirow[t]{2}{*}{ Household income } & & & $0.002 * * *$ & \\
\hline & & & $(5.390)$ & \\
\hline Environmental & & & $-0.001 * * *$ & \\
\hline awareness*household income & & & $(-3.876)$ & \\
\hline \multirow[t]{2}{*}{ Education of head } & & & & $11.630 * *$ \\
\hline & & & & $(2.390)$ \\
\hline Environmental & & & & $-45.616 * *$ \\
\hline awareness*education of head & & & & $(-2.372)$ \\
\hline Observations & 5,530 & 5,530 & 5,530 & 5,530 \\
\hline UIT & 0.000 & 0.000 & 0.000 & 0.000 \\
\hline WIT with critical value & $278.35(11.00)$ & $284.13(11.00)$ & $202.54(11.00)$ & $194.25(11.00)$ \\
\hline OIT & 0.173 & 0.284 & 0.281 & 0.192 \\
\hline
\end{tabular}

Notes: The table reports coefficients and t-statistics (in parentheses) from the estimation of the labor supply equation. Dependent variable is the hours of labor provided by the head of the household and all regressions include the control variables of equation III of Table 3, which are omitted due to space considerations. All variables are defined in Table 1. Estimation method is two-stage least squares with robust standard errors, where the first stage includes instruments constructed using the method of Lewbel (2012) and environmental disease. UIT is the p-value of the under-identification LM test by Kleibergen and Paap, which requires a values lower than 0.05 to reject the null hypothesis at the $5 \%$ level. WIT is the Wald $F$-statistic of the weak identification test by Kleibergen and Paap, which must be higher than its critical value (in parenthesis) to reject the null. OIT is the p-value of the over-identification test by Hansen, which requires a value higher than 0.05 to reject the null hypothesis at the $5 \%$ level. The ***,** and * marks denote statistical significance at the 1, 5 and $10 \%$ level, respectively. 
Table 6

Environmental awareness and polluting consumption: OLS regressions

\begin{tabular}{|c|c|c|c|}
\hline & I & II & III \\
\hline Environmental awareness & $\begin{array}{l}-350.505 * * * \\
(-3.356)\end{array}$ & $\begin{array}{l}-181.963^{*} \\
(-1.805)\end{array}$ & $\begin{array}{l}-209.604^{* *} \\
(-2.022)\end{array}$ \\
\hline Household income & $\begin{array}{l}0.006 * * * \\
(5.964)\end{array}$ & $\begin{array}{l}0.005^{* * * *} \\
(4.975)\end{array}$ & $\begin{array}{l}0.005 * * * \\
(5.120)\end{array}$ \\
\hline Household wealth & $\begin{array}{l}-0.000 * * * \\
(-4.011)\end{array}$ & $\begin{array}{l}-0.000 * * \\
(-2.459)\end{array}$ & $\begin{array}{l}-0.000 * * * \\
(-2.815)\end{array}$ \\
\hline Own house & $\begin{array}{l}94.690 \\
(0.828)\end{array}$ & $\begin{array}{l}319.919 * * * \\
(2.724)\end{array}$ & $\begin{array}{l}318.218 * * * \\
(2.629)\end{array}$ \\
\hline House rooms & $\begin{array}{l}205.548 * * * \\
(10.091)\end{array}$ & $\begin{array}{l}130.569 * * * \\
(6.541)\end{array}$ & $\begin{array}{l}127.388 * * * \\
(6.124)\end{array}$ \\
\hline Mortgage & $\begin{array}{l}508.065^{* * * *} \\
(3.775)\end{array}$ & $\begin{array}{l}230.533^{*} \\
(1.733)\end{array}$ & $\begin{array}{l}256.935^{*} \\
(1.801)\end{array}$ \\
\hline Age of head & & $\begin{array}{l}38.116^{* * * *} \\
(4.588)\end{array}$ & $\begin{array}{l}41.249 * * * \\
(4.710)\end{array}$ \\
\hline Age of head squared & & $\begin{array}{l}-0.581 * * * \\
(-7.350)\end{array}$ & $\begin{array}{l}-0.588 * * * \\
(-7.168)\end{array}$ \\
\hline Gender of head & & $\begin{array}{l}208.210 * * * \\
(2.805)\end{array}$ & $\begin{array}{c}235.215 * * * \\
(3.108)\end{array}$ \\
\hline No. of children & & $\begin{array}{l}147.530 * * * \\
(4.450)\end{array}$ & $\begin{array}{l}169.067 * * * \\
(4.958)\end{array}$ \\
\hline Married head & & $\begin{array}{c}859.341 * * * \\
(10.094)\end{array}$ & $\begin{array}{c}804.896 * * * \\
(9.342)\end{array}$ \\
\hline Health of head & & & $\begin{array}{l}-68.716^{* *} \\
(-2.375)\end{array}$ \\
\hline Education of head & & & $\begin{array}{l}-3.663 \\
(-0.296)\end{array}$ \\
\hline Life satisfaction & & & $\begin{array}{l}-0.663 \\
(-0.023)\end{array}$ \\
\hline Religiosity of wife & & & $\begin{array}{l}0.415 * * * \\
(3.373) \\
\end{array}$ \\
\hline Observations & 8,506 & 8,502 & 8,055 \\
\hline R-squared & 0.135 & 0.188 & 0.197 \\
\hline State dummies & Yes & Yes & Yes \\
\hline
\end{tabular}

Notes: The table reports coefficients and t-statistics (in parentheses) from the estimation of the consumption equation. Dependent variable is the dollar expense of the polluting consumption of the household. All variables are defined in Table 1. Estimation method is OLS with robust standard errors. The ***, **, and * marks denote statistical significance at the 1, 5 and $10 \%$ level, respectively. 
Table 7

Environmental awareness and polluting consumption for the employed

\begin{tabular}{|c|c|c|c|}
\hline & I & II & III \\
\hline Environmental awareness & $\begin{array}{l}-324.563 * * \\
(-2.551)\end{array}$ & $\begin{array}{l}-220.201 * \\
(-1.760)\end{array}$ & $\begin{array}{l}-218.509^{*} \\
(-1.707)\end{array}$ \\
\hline Household income & $\begin{array}{l}0.004 * * * \\
(4.428)\end{array}$ & $\begin{array}{l}0.003 * * * \\
(3.698)\end{array}$ & $\begin{array}{l}0.004 * * * \\
(4.106)\end{array}$ \\
\hline Household wealth & $\begin{array}{l}-0.000 * * * \\
(-2.682)\end{array}$ & $\begin{array}{l}-0.000 \\
(-1.313)\end{array}$ & $\begin{array}{l}-0.000 \\
(-1.587)\end{array}$ \\
\hline Own house & $\begin{array}{l}421.907 * * * \\
(3.276)\end{array}$ & $\begin{array}{l}365.661 * * * \\
(2.817)\end{array}$ & $\begin{array}{l}426.421 * * * \\
(3.256)\end{array}$ \\
\hline House rooms & $\begin{array}{l}206.488 * * * \\
(8.228)\end{array}$ & $\begin{array}{l}129.627 * * * \\
(5.053)\end{array}$ & $\begin{array}{l}134.910 * * * \\
(5.010)\end{array}$ \\
\hline Mortgage & $\begin{array}{l}128.720 \\
(1.097)\end{array}$ & $\begin{array}{l}-17.571 \\
(-0.161)\end{array}$ & $\begin{array}{l}-33.873 \\
(-0.303)\end{array}$ \\
\hline Age of head & & $\begin{array}{l}71.158 * * * \\
(4.540)\end{array}$ & $\begin{array}{l}69.934 * * * \\
(4.368)\end{array}$ \\
\hline Age of head squared & & $\begin{array}{l}-0.870 * * * \\
(-4.871)\end{array}$ & $\begin{array}{l}-0.861 * * * \\
(-4.738)\end{array}$ \\
\hline Gender of head & & $\begin{array}{l}212.709 * * \\
(2.256)\end{array}$ & $\begin{array}{l}252.396 * * * \\
(2.618)\end{array}$ \\
\hline No. of children & & $\begin{array}{l}161.563 * * * \\
(4.008)\end{array}$ & $\begin{array}{l}186.003 \text { *** } \\
(4.483)\end{array}$ \\
\hline Married head & & $\begin{array}{l}857.579 * * * \\
(8.178)\end{array}$ & $\begin{array}{l}758.253 * * * \\
(7.161)\end{array}$ \\
\hline Health of head & & & $\begin{array}{l}10.582 \\
(0.250)\end{array}$ \\
\hline Education of head & & & $\begin{array}{l}-16.200 \\
(-1.010)\end{array}$ \\
\hline Life satisfaction & & & $\begin{array}{l}11.562 \\
(0.269)\end{array}$ \\
\hline Religiosity of wife & & & $\begin{array}{l}1.084 \\
(1.441) \\
\end{array}$ \\
\hline Observations & 5,759 & 5,758 & 5,440 \\
\hline R-squared & 0.110 & 0.144 & 0.155 \\
\hline
\end{tabular}

Notes: The table reports coefficients and t-statistics (in parentheses) from the estimation of the consumption equation. Dependent variable is the dollar expense of the polluting consumption of the household. All variables are defined in Table 1. All three specifications include state dummies. Estimation method is OLS with robust standard errors. The ***,**, and * marks denote statistical significance at the 1,5 and $10 \%$ level, respectively. 
Table 8

Environmental awareness and polluting consumption for the employed: IV regressions

\begin{tabular}{|c|c|c|c|}
\hline & I & II & III \\
\hline \multirow[t]{2}{*}{ Environmental awareness } & $-296.968 * *$ & -206.836 & -183.064 \\
\hline & $(-1.978)$ & $(-1.368)$ & $(-1.247)$ \\
\hline \multirow[t]{2}{*}{ Household income } & $0.004 * * *$ & $0.003 * * *$ & $0.004 * * *$ \\
\hline & $(4.451)$ & $(3.720)$ & $(4.123)$ \\
\hline \multirow[t]{2}{*}{ Household wealth } & $-0.000 * * *$ & -0.000 & -0.000 \\
\hline & $(-2.701)$ & $(-1.322)$ & $(-1.601)$ \\
\hline \multirow[t]{2}{*}{ Own house } & $421.060 * * *$ & $365.530 * * *$ & $426.020 * * *$ \\
\hline & $(3.283)$ & $(2.831)$ & $(3.273)$ \\
\hline \multirow[t]{2}{*}{ House rooms } & $206.392 * * *$ & $129.569 * * *$ & $134.809 * * *$ \\
\hline & $(8.251)$ & $(5.070)$ & $(5.035)$ \\
\hline \multirow[t]{2}{*}{ Mortgage } & 128.922 & -17.614 & -33.795 \\
\hline & (1.104) & $(-0.163)$ & $(-0.304)$ \\
\hline \multirow[t]{2}{*}{ Age of head } & & $71.209 * * *$ & $70.031 * * *$ \\
\hline & & $(4.569)$ & $(4.404)$ \\
\hline \multirow[t]{2}{*}{ Age of head squared } & & $-0.871 * * *$ & $-0.863 * * *$ \\
\hline & & $(-4.902)$ & $(-4.780)$ \\
\hline \multirow[t]{2}{*}{ Gender of head } & & $212.990 * *$ & $252.953 * * *$ \\
\hline & & $(2.271)$ & $(2.640)$ \\
\hline \multirow[t]{2}{*}{ No. of children } & & $161.726 * * *$ & $186.278 * * *$ \\
\hline & & $(4.022)$ & $(4.511)$ \\
\hline \multirow[t]{2}{*}{ Married head } & & $857.301 * * *$ & $757.214 * * *$ \\
\hline & & $(8.218)$ & (7.189) \\
\hline \multirow[t]{2}{*}{ Health of head } & & & 10.807 \\
\hline & & & $(0.257)$ \\
\hline \multirow[t]{2}{*}{ Education of head } & & & -16.561 \\
\hline & & & $(-1.038)$ \\
\hline \multirow[t]{2}{*}{ Life satisfaction } & & & 11.446 \\
\hline & & & $(0.268)$ \\
\hline \multirow[t]{2}{*}{ Religiosity of wife } & & & 1.090 \\
\hline & & & $(1.457)$ \\
\hline \multicolumn{4}{|l|}{ First stage } \\
\hline \multirow[t]{2}{*}{ Environmental disease } & $0.023 * * *$ & $0.020 * * *$ & $0.017 * * *$ \\
\hline & $(2.66)$ & $(2.17)$ & $(1.98)$ \\
\hline Observations & 5,759 & 5,758 & 5,440 \\
\hline UIT & 0.000 & 0.000 & 0.000 \\
\hline WIT with critical value & $34.790(11.07)$ & $44.663(11.03)$ & $70.733(11.01)$ \\
\hline OIT & 0.502 & 0.293 & 0.273 \\
\hline
\end{tabular}

Notes: The table reports coefficients and t-statistics (in parentheses) from the estimation of the consumption equation. Dependent variable is the dollar expense of the polluting consumption of the household. All variables are defined in Table 1. Estimation method is two-stage least squares with robust standard errors, where the first stage includes instruments constructed using the method of Lewbel (2012) and environmental disease. UIT is the p-value of the under-identification LM test by Kleibergen and Paap, which requires a values lower than 0.05 to reject the null hypothesis at the 5\% level. WIT is the Wald $F$-statistic of the weak identification test by Kleibergen and Paap, which must be higher than its critical value to reject the null. OIT is the p-value of the over-identification test by Hansen, which requires a value higher than 0.05 to reject the null hypothesis at the $5 \%$ level. The $* * *$, ** and * marks denote statistical significance at the 1, 5 and $10 \%$ level, respectively. 
Table 9

Heterogeneous effect for households with polluting jobs

\begin{tabular}{llll}
\hline & I & II & III \\
\hline Environmental awareness & -75.407 & -75.008 & -73.225 \\
& $(-0.603)$ & $(-0.588)$ & $(-0.542)$ \\
Pollution intensity of job & $297.23^{* * *}$ & $250.92^{* *}$ & $195.47^{*}$ \\
& $(2.709)$ & $(2.304)$ & $(1.785)$ \\
Environmental awareness* & -104.16 & -86.489 & -116.59 \\
Pollution intensity of job & $(-0.366)$ & $(-0.384)$ & $(-0.622)$ \\
\hline Observations & 5,440 & 5,440 & 5,440 \\
UIT & 0.000 & 0.000 & 0.000 \\
WIT with critical value & $265.55(11.00)$ & $256.40(11.00)$ & $240.77(11.00)$ \\
OIT & 0.741 & 0.656 & 0.651 \\
\hline
\end{tabular}

Notes: Notes: The table reports coefficients and t-statistics (in parentheses) from the estimation of the labor supply equation. Dependent variable is the hours of labor provided by the head of the household and all regressions include the control variables of equation III of Table 8 , which are omitted due to space considerations. All variables are defined in Table 1. Estimation method is two-stage least squares with robust standard errors, where the first stage includes instruments constructed using the method of Lewbel (2012) and environmental disease. UIT is the p-value of the under-identification LM test by Kleibergen and Paap, which requires a values lower than 0.05 to reject the null hypothesis at the 5\% level. WIT is the Wald $F$ statistic of the weak identification test by Kleibergen and Paap, which must be higher than its critical value to reject the null. OIT is the p-value of the over-identification test by Hansen, which requires a value higher than 0.05 to reject the null hypothesis at the $5 \%$ level. The $* * *, * *$ and $*$ marks denote statistical significance at the 1,5 and $10 \%$ level, respectively. 
Table 10

Robustness using data from 2009

\begin{tabular}{|c|c|c|}
\hline & $\begin{array}{l}\text { I } \\
\text { Labor supply }\end{array}$ & $\begin{array}{l}\text { II } \\
\text { Polluting } \\
\text { consumption }\end{array}$ \\
\hline Environmental awareness & $\begin{array}{l}-84.778 * * \\
(-2.401)\end{array}$ & $\begin{array}{l}-32.346 \\
(-0.613)\end{array}$ \\
\hline Household income & $\begin{array}{l}0.001 * \\
(4.451)\end{array}$ & $\begin{array}{l}0.002 * * * \\
(3.743)\end{array}$ \\
\hline Household wealth & $\begin{array}{l}-0.000 * * * \\
(-2.785)\end{array}$ & $\begin{array}{l}0.000 \\
(0.687)\end{array}$ \\
\hline Own house & $\begin{array}{l}-22.954 \\
(-0.637)\end{array}$ & $\begin{array}{l}60.434 \\
(1.130)\end{array}$ \\
\hline House rooms & $\begin{array}{l}19.861 \text { *** } \\
(3.545)\end{array}$ & $\begin{array}{l}17.276 * * \\
(2.481)\end{array}$ \\
\hline Mortgage & $\begin{array}{l}145.338 * * * \\
(4.418)\end{array}$ & $\begin{array}{l}-32.223 \\
(-0.667)\end{array}$ \\
\hline Age of head & $\begin{array}{l}3.989 * * * \\
(3.905)\end{array}$ & $\begin{array}{l}14.543^{* *} \\
(2.389)\end{array}$ \\
\hline Age of head squared & $\begin{array}{l}-0.004 * * * \\
(-3.681)\end{array}$ & $\begin{array}{l}-0.204 * * * \\
(-3.028)\end{array}$ \\
\hline Gender of head & $\begin{array}{l}187.344 * * * \\
(5.908)\end{array}$ & $\begin{array}{l}76.944 * * \\
(2.222)\end{array}$ \\
\hline No. of children & $\begin{array}{l}-3.208 \\
(-0.373)\end{array}$ & $\begin{array}{l}21.502 \\
(1.638)\end{array}$ \\
\hline Married head & $\begin{array}{l}18.767 \\
(0.583)\end{array}$ & $\begin{array}{l}210.609 * * * \\
(4.827)\end{array}$ \\
\hline Health of head & $\begin{array}{l}-33.747 * * * \\
(-3.301)\end{array}$ & $\begin{array}{l}-21.713 \\
(-1.539)\end{array}$ \\
\hline Education of head & $\begin{array}{l}10.969 * * \\
(2.514)\end{array}$ & $\begin{array}{l}(1.543) \\
(-1.038)\end{array}$ \\
\hline Life satisfaction & $\begin{array}{l}-26.798 * * \\
(-2.252)\end{array}$ & $\begin{array}{l}35.446^{*} \\
(1.910)\end{array}$ \\
\hline Religiosity of wife & $\begin{array}{l}11.865 \\
(0.651) \\
\end{array}$ & $\begin{array}{l}-0.933 \\
(-0.033)\end{array}$ \\
\hline \multicolumn{3}{|l|}{ First stage } \\
\hline Environmental disease & $\begin{array}{l}0.028 * * * \\
(2.89)\end{array}$ & $\begin{array}{l}0.022 * * * \\
(2.95)\end{array}$ \\
\hline Observations & 5,470 & 5,361 \\
\hline UIT & 0.000 & 0.000 \\
\hline WIT with critical value & $31.110(11.07)$ & $68.714(11.01)$ \\
\hline OIT & 0.583 & 0.310 \\
\hline
\end{tabular}

Notes: The table reports coefficients and t-statistics (in parentheses) from the estimation of labor (column I) and consumption (column II) equations. All variables are defined in Table 1. Estimation method is two-stage least squares with robust standard errors, where the first stage includes instruments constructed using the method of Lewbel (2012) and environmental disease. UIT is the p-value of the under-identification LM test by Kleibergen and Paap, which requires a values lower than 0.05 to reject the null hypothesis at the 5\% level. WIT is the Wald $F$-statistic of the weak identification test by Kleibergen and Paap, which must be higher than its critical value to reject the null. OIT is the p-value of the over-identification test by Hansen, which requires a value higher than 0.05 to reject the null hypothesis at the $5 \%$ level. The $* * * * *$ and $*$ marks denote statistical significance at the 1,5 and $10 \%$ level, respectively. 
Table A1

Summary statistics

\begin{tabular}{llllll}
\hline Variable & Obs. & Mean & Std. dev. & Min. & Max. \\
\hline Labor supply & 8,907 & $1,490.6$ & $1,066.6$ & 0 & 5,824 \\
Polluting consumption & 8,713 & $2,791.1$ & $2,804.4$ & 0 & 60,000 \\
Environmental awareness & 8,898 & 0.065 & 0.246 & 0 & 1 \\
Household income & 8,907 & $64,873.5$ & $83,647.7$ & $-70,000$ & $2,420,000$ \\
Household wealth & 8,907 & $206,076.7$ & $885,400.1$ & $-990,023$ & $4.25 \mathrm{e}+07$ \\
Own house & 8,907 & 0.529 & 0.499 & 0 & 1 \\
House rooms & 8,700 & 5.293 & 2.418 & 0 & 19 \\
Mortgage & 8,898 & 0.391 & 0.600 & 0 & 9 \\
Age of head & 8,907 & 45.21 & 16.61 & 17 & 98 \\
Gender of head & 8,907 & 0.679 & 0.467 & 0 & 1 \\
No. of children & 8,907 & 0.801 & 1.175 & 0 & 11 \\
Married head & 8,903 & 0.522 & 0.500 & 0 & 1 \\
Health of head & 8,876 & 2.516 & 1.067 & 1 & 5 \\
Education of head & 8,525 & 13.06 & 2.534 & 0 & 17 \\
Life satisfaction & 8,907 & 2.176 & 0.979 & 0 & 9 \\
Religiosity of wife & 8,809 & 18.20 & 116.1 & 0 & 9,490 \\
Polluting job & 8,907 & 0.237 & 0.426 & 0 & 1 \\
Environmental disease & 8,907 & 0.056 & 0.230 & 0 & 1 \\
\hline Notes: The table reports & $164 m b e r$ & $0658 v a t$ & \\
\hline
\end{tabular}

Notes: The table reports the number of observations and summary statistics (mean, standard deviation, minimum, and maximum) for the variables used in the empirical analysis. 
Table A2

Additional sensitivity analyses

\begin{tabular}{|c|c|c|c|c|}
\hline \multirow[b]{2}{*}{ Dependent variable: } & \multicolumn{2}{|c|}{$\underline{\text { Simultaneous Equations }}$} & \multicolumn{2}{|c|}{ Control for other donations } \\
\hline & Labor supply & Consumption & Labor supply & Consumption \\
\hline Consumption & $\begin{array}{l}-0.006 \\
(-0.23)\end{array}$ & & & \\
\hline Labor supply & & $\begin{array}{l}0.350 * \\
(1.88)\end{array}$ & & \\
\hline Environmental awareness & $\begin{array}{l}-121.070 * * * \\
(-2.93)\end{array}$ & $\begin{array}{l}-193.206^{*} \\
(-1.68)\end{array}$ & $\begin{array}{l}-90.805 * * \\
(-2.341)\end{array}$ & $\begin{array}{l}-124.537 \\
(-0.859)\end{array}$ \\
\hline Other donations & & & $\begin{array}{l}60.136 * * * \\
(2.585)\end{array}$ & $\begin{array}{l}210.276^{* *} \\
(2.553)\end{array}$ \\
\hline Household income & $\begin{array}{l}0.002 * * * \\
(12.92)\end{array}$ & $\begin{array}{l}0.004 * * * \\
(5.84)\end{array}$ & $\begin{array}{l}0.001 * * * \\
(4.043)\end{array}$ & $\begin{array}{l}0.004 * * * \\
(4.052)\end{array}$ \\
\hline Household wealth & $\begin{array}{l}0.000 * * * \\
(-5.25)\end{array}$ & $\begin{array}{l}0.000 * * \\
(-2.18)\end{array}$ & $\begin{array}{l}-0.000 * * \\
(-2.238)\end{array}$ & $\begin{array}{l}-0.000 \\
(-1.593)\end{array}$ \\
\hline Own house & $\begin{array}{l}48.083 * * \\
(1.47)\end{array}$ & $\begin{array}{l}330.318 * * * \\
(3.67)\end{array}$ & $\begin{array}{l}62.884 \\
(1.611)\end{array}$ & $\begin{array}{l}398.311 * * * \\
(3.025)\end{array}$ \\
\hline House rooms & $\begin{array}{l}22.933 * * * \\
(3.65)\end{array}$ & $\begin{array}{l}113.917 * * * \\
(6.91)\end{array}$ & $\begin{array}{l}17.897 * * * \\
(3.174)\end{array}$ & $\begin{array}{l}130.400 * * * \\
(4.899)\end{array}$ \\
\hline Mortgage & $\begin{array}{l}135.676 * * * \\
(5.22)\end{array}$ & $\begin{array}{l}210.577 * * * \\
(2.80)\end{array}$ & $\begin{array}{l}-8.645 \\
(-0.229)\end{array}$ & $\begin{array}{l}-40.225 \\
(-0.362)\end{array}$ \\
\hline Age of head & $\begin{array}{l}39.857 * * * \\
(11.03)\end{array}$ & $\begin{array}{l}31.598 * * * \\
(2.79)\end{array}$ & $\begin{array}{l}56.828 * * * \\
(10.009)\end{array}$ & $\begin{array}{l}68.363 * * * \\
(4.300)\end{array}$ \\
\hline Age of head squared & $\begin{array}{l}-0.627 * * * \\
(-17.13)\end{array}$ & $\begin{array}{l}-0.412 * * * \\
(-2.87)\end{array}$ & $\begin{array}{l}-0.694 * * * \\
(-10.793)\end{array}$ & $\begin{array}{l}-0.858 * * * \\
(-4.758)\end{array}$ \\
\hline Gender of head & $\begin{array}{l}81.528 * * * \\
(2.59)\end{array}$ & $\begin{array}{l}201.705^{* *} \\
(2.27)\end{array}$ & $\begin{array}{l}156.154 * * * \\
(4.707)\end{array}$ & $\begin{array}{l}263.501 * * * \\
(2.747)\end{array}$ \\
\hline No. of children & $\begin{array}{l}-47.550 * * * \\
(-4.50)\end{array}$ & $\begin{array}{l}196.736 * * * \\
(6.78)\end{array}$ & $\begin{array}{l}-30.043 * * * \\
(-3.122)\end{array}$ & $\begin{array}{l}189.120 * * * \\
(4.580)\end{array}$ \\
\hline Married head & $\begin{array}{l}127.065^{* * *} \\
(3.43)\end{array}$ & $\begin{array}{l}753.818 * * * \\
(8.19)\end{array}$ & $\begin{array}{l}53.110 \\
(1.572)\end{array}$ & $\begin{array}{l}733.810 * * * \\
(6.973)\end{array}$ \\
\hline Health of head & $\begin{array}{l}-136.636 * * * \\
(-12.86)\end{array}$ & & $\begin{array}{l}-17.767 \\
(-1.480)\end{array}$ & $\begin{array}{l}16.929 \\
(0.403)\end{array}$ \\
\hline Education of head & $\begin{array}{l}15.934 * * * \\
(3.66)\end{array}$ & & $\begin{array}{l}7.234 \\
(1.501)\end{array}$ & $\begin{array}{l}-26.329 \\
(-1.615)\end{array}$ \\
\hline Life satisfaction & $\begin{array}{l}-22.755^{* *} \\
(-2.10)\end{array}$ & & $\begin{array}{l}-28.378 * * \\
(-2.228)\end{array}$ & $\begin{array}{l}6.783 \\
(0.158)\end{array}$ \\
\hline Religiosity of wife & $\begin{array}{l}-0.112 \\
(-1.35)\end{array}$ & & $\begin{array}{l}-0.123 \\
(-0.495)\end{array}$ & $\begin{array}{l}0.970 \\
(1.312)\end{array}$ \\
\hline Observations & & & 5,530 & 5,440 \\
\hline
\end{tabular}

